\title{
Determinants of Women Business Growth: Evidence from Micro and Small Scale Enterprises in Hawassa City Administration, Sidama Regional State, Ethiopia
}

\author{
Kanbiro Orkaido ${ }^{1}$, Bekele Youna ${ }^{2}$ \\ ${ }^{1}$ Department of Accounting and Finance, Pharma College, Hawassa, Ethiopia \\ ${ }^{2}$ Department of Pharmacy, Pharma College, Hawassa, Ethiopia \\ Email address: \\ kanbiroorkaido@yahoo.com (K. Orkaido)

\section{To cite this article:} \\ Kanbiro Orkaido, Bekele Youna. Determinants of Women Business Growth: Evidence from Micro and Small Scale Enterprises in Hawassa \\ City Administration, Sidama Regional State, Ethiopia. American Journal of Theoretical and Applied Business. Vol. 6, No. 4, 2020 , pp. 79-90. \\ doi: $10.11648 /$ j.ajtab.20200604.15
}

Received: September 18, 2020; Accepted: October 9, 2020; Published: November 23, 2020

\begin{abstract}
Increasing number of women-owned business enterprises has left its mark on the global economy by generating job opportunities, improves women's economic empowerment, gender equality in business, and sustainable economic growth. So studying the topic determinants of women business growth is burning issue that attracted the attention of researcher across the world. To this end, the purpose of this study was to identify factors affecting women operated business growth with reference to MSEs in Hawassa city. In order to achieve this objective, the researchers have used explanatory type research design and quantitative research approach in which six hypotheses have been tested. Primary data has been collected using structured questionnaires. Based on the regressions result, this study revealed that access to finance, access to land, access to technology, communication skill, training and increase in tax amount has statistically significant effect on growth of women operated MSEs in Hawassa city. Also access to land was the best predictor of women business growth and lack of training was the least predictor of women business growth in the study area. Based on the finding of the study, the researchers concluded the growth of women micro and small scale enterprises was significantly influenced individual, organizational and environmental factors incorporated in the model.
\end{abstract}

Keywords: Women Operated Micro and Small Scale Enterprise, Business Growth, Hawassa City, Sidama Regional State

\section{Introduction}

Role of women micro and small-scale enterprises are very crucial towards economic growth in developing countries like Ethiopia for the reason they create the job opportunities and improving living standards of people. MSEs Play an important role in creating employment opportunities mainly for the urban youth and women, serve as an engine to transform economies from agricultural-led to industrial led, and are considered the best mechanisms by which citizens accumulate capital and empower women economically [1620].

The role of Micro and Small Enterprises (MSEs) in employment and income generation is increasingly recognized for the unemployed people, especially for women, and has become a major playing field for policymakers and donors with dual objectives of enhancing growth and alleviating poverty. MSEs are particularly important for women since they offer a more flexible, less restrictive form of employment and can be undertaken by the skill they [46-51]. These will be possible if their business growth of MSEs sustains. To this end, studying the determinants of women business growth should be solved as much as possible. Hence, studying the determinants of growth of women operated Micro and small-scale enterprises can be an important subject.

According to studies by $[6-8,17,20,25,26,28-30,32,33$, $37,57,58]$ lack of own land, financial access, inadequate access to training, access to technology and, increase in tax amount are key factors that significantly influence the growth 
of MSEs. However, the present research is different from aforementioned empirical evidence in Ethiopia by adding one more additional variable (communication skill) in the multiple linear regression model to predict the effect of explanatory variables on growth of women operated micro and small enterprises in Hawassa city and cover time gap of two years from 2018 up to 2020 .

As far as the researcher's knowledge and review of literature is concerned, there is no research conducted on the factors affecting growth of women operated micro and small scale enterprise based on evidence from Hawassa city administration of Sidama regional state with exactly similar topic. Hence, undertaking this research in Hawassa city of the region then help to specifically know the determinants of women business growth and take appropriate action in reducing problems related to women business growth and can be also used as an input for policy formulation with regarding the issue of women business growth. And so, by taking in to account these reasons, this study was focused on determinants of business growth of women operated micro and small scale business in Hawassa city administration, Sidama Regional State, Ethiopia.

\section{Literature Review}

\subsection{Definitions of Small and Micro Enterprise}

According to [18] micro and small enterprises agency, the revised definition of MSEs by the Ethiopian government will be used in this study. Accordingly, employment and assets have been used to define MSEs.

Table 1. Definitions of Small and Micro Enterprise.

\begin{tabular}{llll}
\hline Level of enterprise & Sector & Employment & Total asset (in Birr) \\
\hline \multirow{2}{*}{ Micro enterprise } & Industry & $\leq 5$ & $\leq 100,000$ \\
& Service & $\leq 5$ & $\leq 50,000$ \\
Small enterprise & Industry & $6-30$ & $\leq 1.5$ million \\
& Service & $6-30$ & $\leq 500,000$ \\
\hline
\end{tabular}

Source: FDRE (2011).

Besides, the ministers proclamation number 201/2011 defines the micro enterprises as an enterprise having total capital of $\mathrm{Br} 50,000$ not including building for service enterprise or not exceeding $\mathrm{Br} 100,000$ for industrial enterprise. The proclamation also defines small scale enterprise as an enterprise having to total capital of $\mathrm{Br} 50,001$ to 100,000 not including building and having 6-30 number of employees for service or having capital of $\mathrm{Br} 100,001$ to $1,500,000$ for industry.

\subsection{Growth of Women Enterprises}

According to studies [1-6] women MSEs are key drives of economic success, because they are job creator, sales generators and the source of tax revenue. These authors base their assertion on the facts that a large percentage of SMEs contribute to the various countries gross domestic product, they employ a large percentage of the workforce and the high ratios of small businesses to large businesses in the countries concerned.

There are six best ways of measuring growth of SMEs. These are Customer demand, Revenue, Profits and losses, Market share, Workforce health, and Sales. In order to easily calculated and obtain accurate data for analysis, the researcher will use growth of sales. The growth of women small businesses can be measured in terms of productivity, job growth, and increase in number of employees, wages, innovation and export performance within the same industry subgroups.

The empirical findings of studies [19-25] the role of MSEs in prompting economic growth of the nation was too high. However, in developing countries like Ethiopia, female entrepreneurs are facing various challenges in their day-today lives just because of their gender. Financial problems, lack of managerial and entrepreneurial skills, workplace and marketing problems, inadequacy of infrastructural facilities, unpredictable supply of raw materials are among the problems they face. In order to alleviate the situation, the government of Ethiopia should provide female entrepreneurs with access to credit, supply them with a place to work, create a market link for MSEs with raw material suppliers, medium and large firms, make capacity-building training available to improve their business management skills, and provide information on market opportunities and appropriate/improved technologies.

The growth of MSEs can be measured through either in financial or non- financial indicators [2-5]. According to [10-12] the growth of Micro and Small was measured through five point Likert scale starts from (Highly decreased $=(1), \quad$ Decreased $=(2), \quad$ Constant $=(3)$, Improved $=$ and Highly improved $=(5)$ ) by taking in to account the growth indicators such as increase number of employees, sales volumes, market share, customer base, and assets growth using growth as continuous random variable that will be measured through five point Likert scale. On other growth measurements using indicators consist of 3 that growth in sales, profits, and capital. Using descriptive analysis and path analysis to examine the direct and indirect relationship of individual factors and organizational factors on the growth of MSEs.

\subsection{Empirical Review and Hypothesis Development}

According to [38-40], women small and micro Enterprises (MSEs) are still an issue that is interesting to study because it is recognized that small businesses have a major role in employment and contribution to the gross domestic product. Previous research shows that the growth of SMEs is determined by the owner/manager characteristics (personal approach), and how the strategy is taken (managerial approach). This study empirically tested the three determinants of growth of small businesses, namely 1) the individual factors 2) organizational factors, and 3) environment factors. Also other researchers such as by [17, $21,22,26,57]$ found out that the major determinants of business growth of women enterprises were access to 
finance, access to land, access to technology, communication skill, lack of training, and tax amount. By taking in to account the above views, the researcher elaborated the discussion of variables and developed the research hypotheses as follow:

a) Individual factors

Communication skill: Communication is base for individuals, business entities, government entities, nations and continents in the world to share their ideas for different purposes. Hence, women entrepreneurs need communication skills to promote their business products. It is difficult to increase the business performance with effective communication skills and strategies. To this end the study by [28] found out that having communication skills has positive influence on success of small-scale enterprises in Hawassa, Ethiopia.

H4: There is a significant and positive relationship between communication skill of women and business growth.

Lack of Training (LT): Lack of sufficient training for women is a barrier to women involvement in entrepreneurial activities. Non-availability of the training program and technical support are affected women entrepreneurs [1-3] and [58] training support have no significant impact on the success of WSSEs at Southern, Ethiopia. The gender differences in efficiency-driven countries based on the GEM data through correlation and regression analyses. An important finding of their study was that training on starting a new business as a common factor, has a greater influence on female entrepreneurial activity. Therefore, training should be considered an essential issue when designing government policies and stimulating entrepreneurial activity in general, particularly women.

H5: Lack of training has negative and statistically significant influence on growth of women business

b) Organizational Factors

Access to finance (ATF): The financial aspects of setting up an enterprise are without misgiving the most significant barriers to women [59] Women entrepreneurs find it difficult to increase the start-up capital and addition investment for expanding their existing business. Studies by [26] found out that access to finance has positive influence on success of WSSEs in and [29] in his on the same topic suggested that access to finance has positive and significant influence on business performance WSSEs in Konso, Karat town and Tabor sub-city Hawassa respectively. In opposite way [15, 21, $44,58]$ study, results indicated that inadequate capital due to lack of access to credit facilities were the main factor that affecting the growth of MSEs owned women. Hence, it is hypothesized as:

H1: There is a significant and positive relationship between access to finance and women business growth

Access to Land facility: Having sufficient land facility in establishing will have positive influence on business performance of women. Therefore, by $[7,17,20,25,26,28$, $37,57,58])$ found out that lack of sufficient operational land has positive influence on business performance of women. Hence, in this research it can be tentatively stated as:
H2: Having access to land has positive influence on women business growth.

c) Environment Factors

i. Access to technology (AT)

It is virtually not possible for an enterprise to exist without technological resources such as computers, telephones access to internet and e-mail $[1,17,21,22,26,57]$. The company is manufacturing a particular high-tech'product, technological expertise will be significant. It can be considered as dummy variable that can be.

H3: There is a significant and positive relationship between access to finance and women business growth.

ii. Increase in tax amount

There are many laws and regulations in developing countries that women found them hard to obey with and they avert them from conducting a business. Women entrepreneurs depict that taxation and regulations obstacles can play as significant constraints for women entrepreneurs and involve of their self-enterprise. Empirical studies by [29-49] found out that increase in tax amount of the country towards small scale are negatively related with their business growth.

H6: There is a negative and statistically significant relationship between increase in tax amount and women business growth.

\subsection{Conceptual Frame Work of the Study}

The conceptual framework is developed based on the independent variables access to finance, access to land, access to technology, communication skill, training and increases in tax amounts the rectangles at the left side has significant impact on dependent variable (women business growth) in the rectangle at right side as follow:

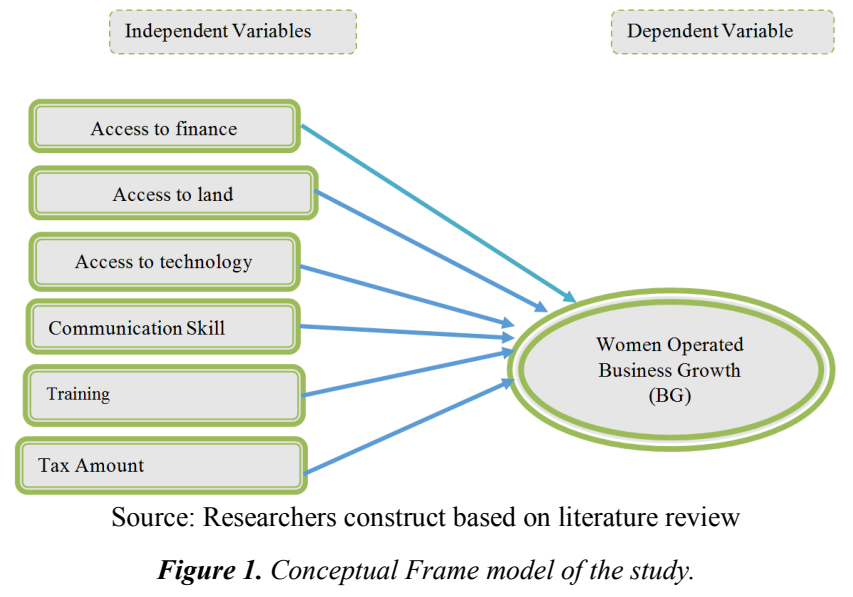

\section{Research Methodology}

\subsection{Research Approach}

In conducting any research, there are three research approaches. These are quantitative, qualitative and mixed research approach. Quantitative research is a means for testing objective theories by examining the relationship among variables. On the other hand, qualitative research 
approach is a means for exploring and understanding the meaning individuals or groups describe to a social or human problem with intent of developing a theory. Lastly, mixed methods approach is an approach in which the researchers emphasize the research problem and use all approaches available to understand the problem [10-13]. Mixed methods research is an approach to an inquiry involving collecting both quantitative and qualitative data, integrating the two forms of data, and using distinct designs that may involve philosophical assumptions and theoretical frameworks. The research approach that was employed in this study quantitative research approach.

\subsection{Research Design}

A research design is the arrangement of conditions for collection and analysis of data in a manner that aims to combine relevance to the research purpose with economy in procedure. When the purpose of research is to test a research hypothesis, it is termed as hypothesis-testing research with explanatory design. This study has aimed to examine factors affecting growth of women operated micro and small scale enterprise in Hawassa city admiration. To do this, the design that will be employed by the researcher is explanatory design which enables to explain the cause and effect relationship between (6) six independent variables like access to finance, access to land, access to technology, communication skill, training and increase in tax amount on dependent variable which is growth of micro and small-scale enterprises in Hawassa.

\subsection{Target Population, Sample Size and Selection Techniques}

The target population of the study is 7,059 women operated MSEs in Hawassa city administration. In order to determine sample size from the total 7,059 women SMEs, the researchers used simple random sampling technique and employed the scientific formula of [60] that takes $95 \%$ of confidence interval for sample size selected of the pupulation. This implies the sample data $95 \%$ populationdata and the remaining $5 \%$ is error this is calculated is follows:

$$
n=\frac{N}{1+(e) 2 * \mathrm{~N}}
$$

Where: $\mathrm{n}=$ sample size

$\mathrm{N}=$ population size

$\mathrm{e}=$ Precision level or sampling error $=0.05$

$$
n=\frac{7,059}{1+(0.05)^{2} * 7,059}=378
$$

Source: [60]

Then, the researcher used stratified sampling technique and showed in the following 2. This is:

$$
n h=(N h / N s) * n
$$

Where, nh=sample size from each site, $\mathrm{Nh}=$ total population in each area, $\mathrm{Ns}=$ target population and $n=$ sample size from target population using stratified sampling

\begin{tabular}{|c|c|c|c|c|}
\hline No & Name of branches & Number of women MSEs in each sub-city & Formula & Sample size \\
\hline 2 & Mengharia Sub-city & 1,119 & $(1119 / 7059) * 378$ & 60 \\
\hline 3 & Tabor Sub-city & 1,471 & $(1471 / 7059) * 378$ & 78 \\
\hline 4 & Tulla Su-city & 628 & $(628 / 7059) * 378$ & 33 \\
\hline 5 & Hikdar Su-city & 115 & $(115 / 7059) * 378$ & 6 \\
\hline 6 & Misrak & 1431 & $(1431 / 7059) * 378$ & 77 \\
\hline 7 & Bahil Adrash & 1087 & $(1087 / 7059) * 378$ & 58 \\
\hline 8 & Addis Ketema & 604 & $(604 / 7059) * 378$ & 32 \\
\hline 9 & Mehal Ketema & 604 & $(604 / 7059) * 378$ & 32 \\
\hline Total & & 7,059 & $(7059 / 7059) * 378$ & 378 \\
\hline
\end{tabular}
technique.

Table 2. Stratified Sampling Size Determination.

Source: MSEs developing agency in Hawassa (2020).

Hence, the representative sample size for this study is 378 women operated MSEs in Hawassa city administration. In summary, the researcher selected sample size using probability sampling that consists, simple random at first stage and then stratified sampling size determination

\subsection{Types of Data, Sources of Data and Method of Data Collection}

The type of data to be used in this research were a nature of both types: qualitative and quantitative types. Questionnaire is the means of data collection from the targeted group of respondents in the women operated micro and small scale enterprise. The questionnaire was composed of both open-ended and close-ended types to get the opinion of the directors on the topic specified. The sources of primary data are respondents selected in each sector. The source of secondary data will be annual reports, journals, websites etc.

\subsection{Methods and Procedures of Data Collection}

In this research, the researchers used both primary and secondary data. To collect primary data structured questionnaires were used to collect primary data from sample of women entrepreneurs. The questionnaire has been prepared in both Amharic and English languages that helps to reduce language understanding barriers and the role of enumerators is so crucial in interpreting the questionnaire from Amharic to English and vice versa for validity matters. 
The questionnaires has been adopted and developed with some modification from previous similar studies such as [8, $9,17,28,34]$ close ended questionnaires were prepared in the form of Likert-scale. The Secondary data was be obtained from review of SMEs annual reports, journals, articles, text books, other related researches in library and internet websites starting from the very beginning to define terms, develop ideas, theories and empirical literature review and development of conceptual framework of the study.

\subsection{Variables and Measures}

Table 3. Summary of Variables description and their scale of measurement.

\begin{tabular}{|c|c|c|c|}
\hline Variables & Symbol & $\begin{array}{l}\text { Scale of } \\
\text { measurement }\end{array}$ & $\begin{array}{l}\text { Expected } \\
\text { sign }\end{array}$ \\
\hline \multicolumn{4}{|l|}{ Dependent variable } \\
\hline $\begin{array}{l}\text { Business Growth: it can be defined as the overall business activities performed by women entrepreneur in micro } \\
\text { and small scale enterprises. Growth is continuous random variable in its nature. It can be measured using } \\
\text { financial indicators or nonfinancial indicators. In this study non-financial indicators i.e. which is subjective } \\
\text { measurement of growth will be used to measure business growth of women MSEs operating in Hawassa city } \\
\text { administration due to non-availability of adequate financial data }\end{array}$ & BP & Continuous & \\
\hline \multicolumn{4}{|l|}{ Explanatory variables } \\
\hline $\begin{array}{l}\text { Access to finance: Access to finance is the availability of money in the form of credit from the financial } \\
\text { institutions for the business runners. Having sufficient credit alternative for financing will have positive influence } \\
\text { on business performance of women. It can be considered as continuous variable. }\end{array}$ & ATF & Continuous & + \\
\hline $\begin{array}{l}\text { Access to Land: Having sufficient land facility in establishing will have positive influence on business } \\
\text { performance of women. It can be considered as continuous which will be measured by using five point Likert } \\
\text { scale. }\end{array}$ & ATL & Continuous & + \\
\hline $\begin{array}{l}\text { Access to technology: It is virtually not possible for an enterprise to exist without technological resources such as } \\
\text { computers, telephones access to internet and e-mail. It can be considered as continuous variable that can be } \\
\text { measured through five point Likert scale of measurement. }\end{array}$ & ATR & Continuous & + \\
\hline $\begin{array}{l}\text { Training: Training is the skill acquire through education and knowledge sharing. It can be off the job and on the } \\
\text { job training. But probably on the job training is advisable for business runners. Lack of sufficient training for } \\
\text { women is a barrier to women involvement in entrepreneurial activities. Non-availability of the training program } \\
\text { and technical support are affected women entrepreneurs }\end{array}$ & LTR & Continuous & - \\
\hline $\begin{array}{l}\text { Increase in tax amount: Tax is money that is levied over from the revenue that is generated from doing business. } \\
\text { Tax is the continuous variable in its nature that can be measured on continuous scale of measurement. Women } \\
\text { entrepreneurs depict that increase in tax amount is an obstacles can play a significant constraints for women } \\
\text { entrepreneurs and involve of their self-enterprise. }\end{array}$ & TA & Continuous & - \\
\hline $\begin{array}{l}\text { Communication skill: is the overall interpersonal dynamic skill that the owners of the business and their } \\
\text { employees possess to attract customers thereby to boost business performance. }\end{array}$ & $\mathrm{CS}$ & Continuous & + \\
\hline
\end{tabular}

Source: Own construct of researchers.

\subsection{Assessment of Classical Linear Regression Assumptions}

The following diagnostic tests were carried out to ensure that the suits the basic assumption of classical linear model. Among the assumption, the researcher conducted four basic diagnostic tests to check if the data meet the requirement. Normality, Multicollinearity, autocorrelation, and heteroscedasticity tests were undertaken.

\subsection{Econometric Model Specification}

Growth of Micro and Small scale is defined as the overall business activities performed by MSEs. Empirical view of [5, $12,44]$ used growth indicators such as increase number of employees, sales volumes, market share, customer base, and assets growth using Likert scale. So, the researcher considered growth as continuous random variable that will be measured through five point Likert scale. Growth is continuous random variable in its nature that could be measured through multiple Regression Model (MLRM). A model is said to be linear when it is linear in parameters. Linear regression model can be either simple or multiple.
Simple linear regression model is used when there is only one independent variable. The researchers has specified the multiple linear regression model (OLS), the regressed (dependent variable: Women Business Growth (WBG) is a linear function of Explanatory variables including, Access to finance (ATF), access to Land premise (ALP), Access to technology (AT), communication skill (CS), Lack of Training (LT) and increase in tax amount (TA), Continuous (independent variables) corresponding to the explanatory variables and a random disturbance or error. The model also has an intercept. Designating the regressed by $\mathrm{BP}$, the independent variables such as FR, WI, AG, EL....... PI. And the random disturbance- by $u$, the population model of multiple linear regressions is given by the following expression as:

$$
\begin{gathered}
W B G=\beta 0+\beta 1 * A T F+\beta 2 * A T L+\beta 3 * A T+\beta 4 * \\
C S K+\beta 5 * L T+\beta 6 * T A+u
\end{gathered}
$$

Whereas:

WBP=Women Business Growth

$\beta 0=$ Constant term

$\beta 1, \beta 2, \beta 3, \beta 4$ and $\beta 6$ refers to coefficients of independent 
variables

$\mathrm{ATF}=$ Access to Finance

$\mathrm{ATL}=$ Access to land

$\mathrm{AT}=$ Access to technology

$\mathrm{CSK}=$ Communication skill

LT $=$ Lack of Training

$\mathrm{TA}=$ Tax amount

\subsection{Methods of data Analysis}

After accomplishment of data collection procedure, it should have classified as per each variable, the qualitative data was coded to be measured quantitatively. In this research data, were analyzed by descriptive statistics such as maximum and minimum values, average, correlation, frequency, percentage, variance and standard deviation and inferential statistics (logistic regression) by the help of SPSS Version 23.0 in order to get the reliable finding.

\subsection{Reliability, Validity Test and Ethical Considerations}

Reliability test of the average value of the questionnaire was measured by using a pilot test to be carried out by the researchers before actual data analysis.

Table 4. Reliability test.

\begin{tabular}{lll}
\hline Cronbach's Alpha & $\begin{array}{l}\text { Cronbach's Alpha Based on } \\
\text { Standardized Items }\end{array}$ & N of Items \\
\hline 0.766 & 0.762 & 7 \\
\hline
\end{tabular}

Source: Survey data, 2020.

This indicates that all the items under consideration accounts above the scientifically accepted threshold, therefore the data were reliable under this circumstance. Compared with the minimum value of alpha 0.70 advocated by Cronbach's, then the responses generated for all of the 7 items 'used in this research were reliable enough for data analysis. This implies that the data incorporated in SPSS is reliable

Validity Test: Validity test was established using a pilot test by collecting data from 10 subjects, and these will be not included in the sample. Data collected from pilot test will be analyzed using SPSS (Statistical Package for Social Sciences) version 21.0

Ethical Considerations: The ethical considerations have been given attention by the researchers and enumerators while conducting the research that includes voluntary participation, no harm were to participants, anonymity and confidentiality, not deceiving the subjects and privacy of participants. Conserving the voluntary participation of respondents, no participants were forced to take part in the research and participants were free to withdraw from the research at any moment. With regarding to harm to participants, the researcher ensured that there is no any physical or psychological harm done to the participants as a result of the study. When it comes to Anonymity and confidentiality, all information gathered during the study will be handled confidentially and permission from the participants was obtained for all information to be shared publicly. Not deceiving the subjects since participants will be informed clearly about the aim, purpose and procedures of the study and will not deceived in any way. Finally, Privacy of participants the privacy of the participants will be respected.

\section{Results}

\subsection{Response Rate}

This part deals with analysis of the data that was collected through structured questionnaire from growth of women small-scale enterprise in Hawassa city. To this end, the researchers distributed three hundred seventy eight (378) questionnaires. Out of the 378 questionnaires distributed, two hundred eighty one (281) questionnaires were correctly filled and returned. This implies that the response rate of the questionnaire was $(74.33 \%)$ which indicates more than half of respondents were participated in the process of data collection. Then, the data analysis was done using the statistical package for social science version 21.0 by both descriptive and inferential statistics analysis based on 281 questionnaires properly collected. Descriptive and inferential analysis were made by multiple regression model.

\subsection{Summary of Descriptive Statistics}

Table 5. Summary of Descriptive Statistics.

\begin{tabular}{|c|c|c|c|c|c|}
\hline & $\mathbf{N}$ & Minimum & Maximum & Mean & Std. Deviation \\
\hline Women business Growth & 281 & 1.00 & 4.00 & 2.5979 & 1.04122 \\
\hline Access to Finance & 281 & 1.00 & 5.00 & 2.1886 & 1.14487 \\
\hline Access to land & 281 & 1.00 & 5.00 & 2.7865 & 1.20888 \\
\hline Access to technological resources & 281 & 1.00 & 5.00 & 2.9039 & 1.29063 \\
\hline Communication skill & 281 & 1.00 & 5.00 & 2.9822 & .99087 \\
\hline Training & 281 & 1.00 & 5.00 & 2.3737 & 1.00315 \\
\hline Increase in Tax Amount & 281 & 1.00 & 5.00 & 2.8505 & 1.24459 \\
\hline
\end{tabular}

Source: Survey data, 2020.

Women business growth was the dependent variable of this study. As indicated in the above table 5, the women business performance of the sectors (WBG) shows that the sectors achieved on average a positive women business growth. For the total sample, the overall mean of WBG was 26.014 percent with a maximum of 5 and a minimum of 1 Likert 
scale values. Regarding the standard deviation, it is mean to both sides by 10.47 percent, which indicate there was variation from the mean. This implies that the sectors need to optimize the use of their assets to increase the women business growth of the sectors. With regard to the access to finance (ATF), the overall mean was 21.886 percent. This implies that on average, most business sectors access to finance was contributing for women business performance of the business sectors in Hawassa city administration. The minimum and maximum values of the ATF are one and five respectively. The mean value of overall ATF deviates from its mean to both sides by 11.2443 percent.

The mean of the Access to Land (ATL) was 2.7865 percent. ATL was slowly dispersed from its mean value with the standard deviation of 1.20888 percent. The maximum and minimum values of the size of the sectors were five and one respectively. The mean of the Access to Technological Resources (ATR) was 2.9039 percent. This implies that ATR averagely contributes to WBG at about 2.9039. ATR was slowly dispersed from its mean value with the standard deviation of 1.29063 percent. The maximum and minimum values of the size of the sectors were five and one respectively. The average value of the Communication Skill (CS) was 2.9822 percent. This implies that on average, Communication Skill (CS) increased by 2.9822 percent.

The outputs of the descriptive statistics of the Training
(TR) data indicate that the mean of women business performance was 2.3737 and standard deviation 1.00315 percent. This means that on average 2.3737 percent of training as percentage of total women business performance with maximum value of Likert scale 5 and a minimum value of 1 respectively. The average value for increase in Tax Amount (TA) as measured by five point Likert was 2.8505 percent. The standard deviation is 1.24459 percent and maximum of five and the minimum of one percent respectively since measured on five point Likert scale. To sum up from among the variables included in this study access to finance (ATF) and training (TR) with mean of 2.1886 and 2.3737 respectively have low mean whereas the rest variables fall within the range of medium/moderate mean scale.

\subsection{Pearson Correlation Matrix for Dependent and Independent Variables}

Correlation analysis measures the relationship between two items. The resulting value (called the "correlation coefficient) shows if changes in one item will result in changes in the other item. Correlation is a way to index the degree to which two or more variables are associated with or related to each other. The correlation matrix for this study was computed as follow:

Table 6. Pearson correlation matrix for dependent and independent variables.

\begin{tabular}{|c|c|c|c|c|c|c|c|c|}
\hline Varial & & WBG & ATF & ATL & ATR & CS & TR & TA \\
\hline \multirow{2}{*}{ WBG } & Pearson Correlation & 1 & $.489^{* *}$ & $.584^{* *}$ & $.237^{* *}$ & $.305^{* *}$ & $-.245^{* *}$ & $.370^{* *}$ \\
\hline & Sig. (2-tailed) & & .000 & .000 & .000 & .000 & .000 & .000 \\
\hline \multirow{2}{*}{ ATF } & Pearson Correlation & $.489^{* *}$ & 1 & $.458^{* *}$ & $.242^{* *}$ & -.117 & $.383^{* *}$ & $.318^{* *}$ \\
\hline & Sig. (2-tailed) & .000 & & .000 & .000 & .051 & .000 & .000 \\
\hline \multirow{2}{*}{ ATL } & Pearson Correlation & $.584^{* *}$ & $.458^{* *}$ & 1 & $-.345^{* *}$ & .048 & $-.320^{* *}$ & $.691^{* *}$ \\
\hline & Sig. (2-tailed) & .000 & .000 & & .000 & .428 & .000 & .000 \\
\hline \multirow{2}{*}{ ATR } & Pearson Correlation & $.237^{* *}$ & $.242^{* *}$ & $-.345^{* *}$ & 1 & $.295^{* *}$ & $.373^{* *}$ & $-.289^{* *}$ \\
\hline & Sig. (2-tailed) & .000 & .000 & .000 & & .000 & .000 & .000 \\
\hline \multirow{2}{*}{$\mathrm{CS}$} & Pearson Correlation & $.305^{* *}$ & -.117 & .048 & $.295^{* *}$ & 1 & $-.230^{* *}$ & $.276^{* *}$ \\
\hline & Sig. (2-tailed) & .000 & .051 & .428 & .000 & & .000 & .000 \\
\hline \multirow{2}{*}{ TR } & Pearson Correlation & $-.245^{* *}$ & $.383^{* *}$ & $-.320^{* *}$ & $.373^{* *}$ & $-.230^{* *}$ & 1 & $-.264^{* *}$ \\
\hline & Sig. (2-tailed) & .000 & .000 & .000 & .000 & .000 & & .000 \\
\hline \multirow{2}{*}{ TA } & Pearson Correlation &.$-370^{* *}$ & $.318^{* *}$ & $.691^{* *}$ & $-.289^{* *}$ & $.276^{* *}$ & $-.264^{* *}$ & 1 \\
\hline & Sig. (2-tailed) & .000 & .000 & .000 & .000 & .000 & .000 & \\
\hline
\end{tabular}

**. Correlation is significant at the 0.01 level (2-tailed).

Source: Survey data, 2020.

The table 6 shows the relationship between dependent variable women business growth (WBG) and independent variables with coefficient of correlation 1 indicates that each variable is perfectly correlated with each other. The result shows that, Access to finance (ATF), Access to land (ATL), Access to technological resources (ATR), and Communication skill (CS) were positive and significantly correlated with women business performance at $1 \%$ level of significance. But lack of training and tax amount were negatively correlated and at $1 \%$ significance level (as $\mathrm{P}<0.01$. The result shows the acceptable reliability of the research variables in which, the correlation among predictors were not high and more than 0.80 indicates there are no multicollinearity problems among variables which is best for analysis of the data for this study.

\subsection{The Regression Results (Inferential Statistics)}

The following diagnostic tests were carried out to ensure that the suits the basic assumption of classical linear model. Among the assumption, the researcher conducted four basic diagnostic tests to check if the data meet the requirement. Normality, Multicollinearity, autocorrelation, and 
heteroscedasticity tests were undertaken

Table 7. Regression Results: Women Business Growth (WBG).

\begin{tabular}{|c|c|c|c|c|c|c|c|c|c|c|}
\hline \multicolumn{11}{|c|}{$R=0.810^{a}, R^{2}=0.656$, Adj. $R^{2}=0.648$, Std. Error of the Estimate $=.61745$, Durbin-Watson $(d)=1.972, F-$ statistic $=87.040$, P-value $=0.000$} \\
\hline \multirow{2}{*}{\multicolumn{2}{|c|}{ Model }} & \multicolumn{2}{|c|}{$\begin{array}{l}\text { Unstandardized } \\
\text { Coefficients }\end{array}$} & \multirow{2}{*}{$\begin{array}{l}\text { Standardized } \\
\text { Coefficients } \\
\text { Beta } \\
\end{array}$} & \multirow{2}{*}{ t-value } & \multirow{2}{*}{ Sig. } & \multicolumn{2}{|c|}{$95.0 \%$ Confidence Interval for B } & \multicolumn{2}{|c|}{ Collinearity Statistics } \\
\hline & & B & Std. Error & & & & Lower Bound & Upper Bound & Tolerance & VIF \\
\hline \multirow{7}{*}{1} & (Constant) & .421 & .221 & & 1.904 & .058 & -.014 & .855 & & \\
\hline & ATF & .325 & .053 & .357 & 6.122 & $.000 * *$ & .220 & .429 & .369 & 2.712 \\
\hline & ATL & .451 & .054 & .524 & 8.303 & $.000 * *$ & .344 & .558 & .315 & 3.171 \\
\hline & ATR & .301 & .041 & .373 & 7.287 & $.000 * *$ & .219 & .382 & .480 & 2.083 \\
\hline & $\mathrm{CS}$ & .177 & .048 & .169 & 3.683 & $.000 * *$ & .082 & .272 & .599 & 1.668 \\
\hline & LTR & -.364 & .051 & -.351 & -7.174 & $.000 * *$ & -.464 & -.264 & .524 & 1.907 \\
\hline & ITA & -.115 & .046 & -.137 & -2.518 & $.012 *$ & -.205 & -.025 & .421 & 2.375 \\
\hline
\end{tabular}

$* *$ P- value $<0.01, *$ p-value $<0.05$ level of Confidence, $\mathrm{N}=281$.

Source: Survey data, 2020.

\section{Fitted model}

$$
\begin{gathered}
\mathrm{WBG}=0.421+0.325 * * \mathrm{ATF}+.451 * * \mathrm{ATL}+0.301 * * \mathrm{ATR}+ \\
0.177 * \mathrm{CS}-0.364 * * \mathrm{LTR}-0.115 * \mathrm{TA}+\mathrm{err}
\end{gathered}
$$

The OLS result of was presented in table 6 , above. Rsquared/coefficient of determination was measured the goodness of $f$ it of the explanatory variables in explaining the variations in women business performance. As shown in the table above, R-squared and the Adjusted-R- squared statistics of the model were 65.6 percent and 64.8 percent respectively. The result indicates that 64.8 percent variation in the dependent variable was explained by the explanatory variables in the model. That means the explanatory variables (such as access to finance (ATF), access to land (ATL), access to technological reassures (ATR), Communication skill (CS) and Lack Training (LTR) are jointly explain about 64.8 percent of the variation in the women business Growth of women MSEs operated in Hawassa city. The remaining 36.2 percent of the variation in the women business growth (as measured by Likert scale) explained by other variables which are not included in the model, the so called exogenous variables to the mode contrary to the current model variables/endogenous variables. Besides, the, F- statistics (87.040) in model summary and ANOVA table with ( $p$-value of 0.000 ) which is used to test the overall significance of the model was presented and indicates the reliability and validity of the model at 1 percent level of significance. This tells us that the model as a whole is statistically significant.

The t-value of all variables is outside the lower and upper limit of confidence interval of coefficient which shows that all variables like access to finance, access to land, access to technological reassures, Communication skill and Lack Training that incorporated in the OLS model has statistically significant influence on dependent variable (women business performance).

The unstandardized coefficients of independent variables such as ATF 0.325, ATL 0.451, ATR 0.301 and CS 0.177 implies that one percent increase in variables such as ATF, ATL, ATR, and CS leads to increase in women business performance by $32.5 \%, 45.1 \%, 30.1 \%$, and $17.7 \%$ respectively. Whereas, the unstandardized coefficient of the two explanatory variables such as LTR - 0.364, and TA 0.115 shows that one unit changes in lack of training and increase in tax amount lead to a negative direction changes on dependent variable (WBG).

\section{Discussion}

The result of this study shows that access to finance with standardized coefficient of regression $[\beta=0.325]$ has positive and statistically significant at $1 \%$ level of significance since ( $p$-value of $0.000>0.01$ ). Hence, hypothesis $\mathrm{H} 1$ is accepted. This finding is consistent the finding of other studies results [28] and [29] who found out the positive and significant relationship between access to finance and business performance in their study areas. The finding is in consistent to the empirical findings of [7, 21, 25, $26,57]$ who found lack of access to finance has negative influence on growth of women owned SMEs. The regression result of the model regarding access to be also clearly evidenced that there is statistically significant and positive relationship between access to finance and women business growth in Hawassa as far as the sign is positive. This implies that more access to finance contributes to the growth of women operated in MSEs.

Regarding to the access to land with coefficient of regression of competency of internal audit staff, $[\beta=0.451]$ is positive and statistically significant at $1 \%$ level of significance with ( $p$-value of $0.000>1 \%$ ). Therefore, hypothesis $\mathrm{H} 2$ is accepted. This finding is consistent with that of with general logic that existence own land for operating business enables to accumulate capital since there is no rental payments to the lessor. On other hand, empirical findings of $[7,21,25,26,34,57]$ found out that lack of sufficient operational land premise has negative influence on business performance of women in micro and small scale enterprises the majority of women entrepreneurs have experienced difficulties in finding and acquiring land premises for production or provision of services, as well as for selling purposes. Most run their businesses from rented premises, but the relatively high rents pose critical problems for them and can hinder their expansion and diversification. 
The finding of present study confirms the land availability for running business operation contributes to the business growth of MSEs in Hawassa city Administration. It meaning information for policy makers and MSEs developing bodies to facilitate the land premise for supporting the expansion of women MSEs in one hand and encourage the economic development of the nation on other hand.

With regarding to access to technological resources with coefficient of regression of access to technological resources is $[\beta=0.301]$ is positive and statistically insignificant with (pvalue of 0.000 ) which is significant level of significances. Therefore, hypothesis H3 is accepted. This indicates that availability of technological resources has no influence on performance of the MSEs since it leads to the ineffective resource allocation. Technological resources are very important determinants that influence the performance of women entrepreneurs in micro and small scale enterprises. This finding is consistent with results of $[3,16,19,20,24]$ found out that lack technological resources. So that MSE should access to technological resources since it encourages their business performance.

Regards to communication skill of women MSE is the interaction between the business owners and their respective customers which boosts growth of the business at large. The result of coefficient of regression of access to technological resources is $[\beta=0.177]$ which is positive and statistically significant at $1 \%$ level of significance because the sig of 0.000 is less than $1 \%$. Hence, the H4 is accepted. The result of this study is consistent with studies result of [29, 42] communication skill of enterprise owners/managers with their employees/customers has a significant positive impact on the job performance of the enterprises. The result of this study supports that improvements in communication skills of women micro and small scale enterprise has positive and statistically significant effect on business growth of women

The result of this study shows lack of sufficient training with coefficient of regression $[\beta=-0.364]$ has positive and statistically significant since ( $p$-value of $0.000<0.01$ ). Hence, hypothesis $\mathrm{H} 5$ is accepted. This finding is consistent with finding of other studies results [3, 8, 23, and 31] who found lack of training has negative influence on women SMEs business performance in their study areas. This implies lack of access to training has negative contribution to growth of women operated in MSE in Hawassa city administration.

Lastly, the result of this study shows that increase in tax amount with coefficient of regression $[\beta=-0.115]$ has negative and statistically significant at $5 \%$ level of significance since (p-value of $0.0 .012>5 \%$ level of significances). Hence, hypothesis H6 is accepted. The result is similar with findings of $[26,29,49]$ found out that increase in tax amount of the country towards growth of women micro and small scale are negatively related with their performance.

\section{Conclusion}

In this paper, the researchers have investigated the determinants of women business growth of MSEs operated in
Hawassa city. By keeping this objective in mind, the researcher collected the primary data through selfadministrated or (structured) questionnaire. By using SPSS version 21.0 the analysis of both descriptive and inferential statistics has been done. The conclusion that can be drawn from the findings in the first hypothesis up to fourth hypothesis ( $\mathrm{H} 1, \mathrm{H} 2, \mathrm{H} 3$, and $\mathrm{H} 4)$, stated as "access to finance, access to land, access to technological resources, and communication skill has positive and significant effect on business performance were accepted. This means an increase one unit value the value of access to finance, access to land, access to technological resources, and communication skill were leads to an increase in business growth of women MSEs measured by five point Likert scale. Also, conclusion that can be drawn from the findings of two remaining hypothesis, under the summary of the findings was, hypothesis H5 and H6 stated as "lack of training and increase in tax amount has negative and significant effect on business performance of women were accepted; which shows that an increase on the value of this variable leads to decrease in business growth of women operating in Hawassa, Ethiopia.

In summary, Individual factors such as communication skill and access to training were significantly influence the growth of the business which means businesses with experience and communication skill to be able to read the opportunities, have creative ideas to market changes, so that businesses can grow.

Organizational factors such as access to finance and land affect the growth of the business, which means that more effective means an organization's ability to access to finance and land enables it to run and manage enterprise resources so it will achieve business growth since the company would operate more effectively and efficiently.

Environmental factors such as access to technology and tax amount on profit are key factors for the growth of SMEs, it means the ability of owner / managers to manage the company effectively to be able to anticipate changes in the business environment and competition, will affect business growth. So MSES growth is also determined by environmental factors, required the owner's ability to cope with environmental change imitating new technology that enables the enterprise to grow. In fact, technology facilities are the legitimacy of the business activity. This means the information technology facility is credible within the organization and support business performance of women micro and small scale enterprises. In the current study, it found out that IT facility has positive and statistically significant influence on women business growth. Hence, the MSEs developing should work on technological resource for women business enterprises more than the current one to sustaining the business growth of women efficiently and effectively.

\section{Further Research Direction}

No study is free of limitation; accordingly there are limitations in the current study. Basically it was focused on 
determinants of women small business growth in in Hawassa city administration and it is difficult to generalize to all women's at regional and country level. Hence, the study can be enhanced if it is done at regional and country level and also it is possible if it is done on women entrepreneurs' counterpart, the men entrepreneurs by using different methodology and sampling technique. Additionally it is possible to undertake the comparative study on the same topic and case area between women entrepreneurs and their counterparts, the men entrepreneurs. Further research can also incorporate additional variable other than the current variables of the study as factors affecting growth of women MSEs' business growth that was not incorporated in the current study on the same area or at the regional and country level since the current study tests only six factors.

\section{References}

[1] Abdi Ibrahim Farah. (2017). Factors Influencing women participation in entrepreneurial Activities in Kenya.

[2] Abdirahman Muhamad. (2016). Challenges and Motivations of Women Entrepreneurs in Somali Region of Ethiopia Pp, 169-198.

[3] Afroze, T., Alam, M. K., Akther, E. and Jui, N. S. (2014). Women entrepreneurs in Bangladesh- challenges and determining factors. Journal of Business and Technology (Dhaka), 9 (02): 27-39.

[4] Afzal Hossain, Md. Zillur Rahman Siddique, Md. Abdullah Al Jamil (2018) Factors Affecting Women Involvement as Entrepreneur in SMEs Sector, Economic Development and Its Impact on Poverty Reduction in BangladeshVol. 4, Issue. 5, pp: 51-65.

[5] Agbobli. E. (2015). Entrepreneurship \& Small business development and research. https://www.researchgate.net/post/How_do_I_measure_the_gr owth_of_business_particularly_the_SMEs, $\overline{1} \overline{2}$ th Dec, 2015 .

[6] Ali Yassin Sheikh Ali Hussein Abdi Mahmud. (2013). Motivational Factors and Performance of Women Entrepreneurs in Somalia Journal of Education and Practice Vol. 4.

[7] Alsen Florian Kapinga and Calkin Suero Montero (2017) Exploring the socio-cultural challenges of food processing women entrepreneurs in IRINGA, TANZANIA and strategies used to tackle them, Kapinga and Montero Journal of Global Entrepreneurship Research (2017) 7: 17 DOI 10.1186/s40497017-0076-0.

[8] Andrew Kitavi Wambua (2014). Factors Affecting The Performance Of Women Small And Medium Enterprises In Mombasa Central Business District, Kenya. Research Project Report Submitted In Partial Fulfilment Of The Requirements For The Award Of Master of Arts Degree In Project Planning And Management Of The University Of Nairobi.

[9] Anne Ngima Kinyua. (2014). Factors Affecting the Performance of Small and Medium Enterprises in the Jua Kali Sector In Nakuru Town, Kenya. Journal of Business and Management. Volume 16, Issue 1. Ver. IV (Jan. 2014), PP 80-
93.

[10] Basil T. and Helen T. (2010). Performance on the Right Hand Side: Organizational Performance An independent Variable. School of Commerce, International Graduate School of Business, University of South Australia, Adelaide, Australia. Performance on the RHS 2 Sunday, July 04, 2010.

[11] Bequo, I. and Gehrels, S. A. (2014). Women entrepreneurship in developing countries. Research in Hospitality Management, 4 (1 \& 2): 97-104. Finance. AAU; Ethiopia.

[12] BMG Research. (2013). Small Business Survey - Employers Report. www.nationalarchives.gov.uk/doc/open-governmentlicence.

[13] Caroline Wairimu Kamunyu and Fridah Simba Theuri (2017) Factors Affecting Growth of Women Owned Small and Medium Enterprises in Kenya: A Survey of Women-Led SMEs in South Coast Ukunda, IOSR Journal of Business and Management (IOSR-JBM), Volume 19, Issue 3. PP 6066.

[14] Creswell, J. W. (2009). Research Design Qualitative, Quantitative, and Mixed Methods Approaches (3rd ed.). Thousand Oaks, CA Sage Publications.

[15] Ezilda María Cabrera, David Mauricio. (2017). Factors affecting the success of women's entrepreneurship: a review of literature. International Journal of Gender and Entrepreneurship, Vol. 9 Issue: 1, pp. 31-65.

[16] Fakruddin Ali \& P. Tarangini (2018). Socio Cultural factors influencing Entrepreneurial growth: A study on Small Medium Enterprises: A selected towns-south Ethiopia, RESEARCH REVIEW International Journal of Multidisciplinary Special Issue www.rrjournals.com

[17] Farah, A. I. (2014). Factors influencing women participation in entrepreneurial activities in Mandera Township. Mandera Central Division, Kenya.

[18] FDRE, National planning Commission. (2016). Growth and Transformation Plan II (GTP-2015-2019/2020 (volum one ed.). Addis Ababa: FDRE.

[19] Feyisa, B. D., \& Tamene, K. A. (2019). The Roles of Micro and Small Enterprises in Empowering Women: The Case of Jimma Town, Ethiopia. International Journal of Multicultural and Multireligious Understanding, 6, 139-151.

[20] Gebremariam, F. M. (2017). Factors Affecting the Growth of Women-Operated Micro and Small Enterprises (MSEs) in Ethiopia. Üniversitepark Bülten, 6 (1), 56-66.

[21] Getu Girma. (2015). Factors affecting the Performance of Women Entrepreneurs in Micro and Small Enterprises in Gulele Sub-City, Addis Ababa, Addis Ababa University unpublished master's thesis available online.

[22] GEM or Global Entrepreneurship Monitor/. (2010). Women's report, Entrepreneurs and entrepreneurial employees across the globe.

[23] Gitonga Doris Nkatha (2016). Factors influencing The Performance of Female Owned Enterprises: A Case of Businesses in the Central Business District Of Nairobi, Kenya. A Project Report Submitted In Partial Fulfillment Of The Requirements For The Award Of Master Of Arts In Project Planning And Management Degree Of The University Of Nairobi. 
[24] Hughes, K., Jennings, J., Brush, C., Carter, S., \& Welter, F. (2012). Extending women's entrepreneurship research in new directions. Entrepreneurship Theory and Practice, 36 (3), 429442 .

[25] Isidore Ekpe Norsiah Mat \& Razli Che Razak. (2011). Attributes, Environment Factors and Women Entrepreneurial Activity: A Literature Review.

[26] Jemal Abagissa. (2013). Challenges Confronting Women in Micro and Small Enterprises in Addis Ababa, Ethiopia.

[27] Juliana Anyango. (2015). Constraints Affecting Women In Micro And Small Enterprises In Kasipul Constituency Homabay County- Kenya.

[28] Kanbiro Orkaido Deyganto, Solomon Mitku Mekonen and Degent Bunaro Sodano (2018). Determinants of Micro and Small Enterprises Performance in Karat town, Konso, Ethiopa European Journal of Business and Management www.iiste.org. Vol. 10, No. 31, PP 1-10.

[29] Kanbiro Orkaido and Addisu Karafo (2018). The Impact of Communication Strategies and Access to Finance on the Success of Small-scale Enterprises in Tabor Sub-city, Hawassa. Research Journal of Finance and Accounting Vol. 9, No. 21, PP 57-63.

[30] Karen D. Jennings E., Candida B., Sara C., Friederike W., (2012) Extending Women's Entrepreneurship Research in New Directions.

[31] Kessy, S. (2009), Microfinance and Enterprises Performance in Tanzania: Does Gender Matter? [http://www.microfinancegateway.org/gm/document1.9.41393/Microfinance and Enterprises Performance in Tanzania.pdf] site visited on 12/03/2014.

[32] Kothari, C. (2004). Research Methodology: Methods and techniques. ( 2 nd revised edition ed.). New Delhi: Age International Publishers.

[33] Kumar, R. (2005). Research methodology: a step- by-step guide for beginners (2nd ed ed.). Malaysia: SAGE publications. 1 .

[34] Maziku, Petro, Majenga, Annastazia, Mashenene, Galan Robert. (2014). The Effects of Socio-Cultural Factors on the Performance of Women Small and Medium Enterprises in Tanzania, Journal of Economics and Sustainable Development, Vol. 5, No. 21, pp 51-62.

[35] Menda, S. (2015). The Role of Micro and Small Scale Business Enterprises in Urban Poverty Alleviation: A Case Study on Cobble Stone Paving Sector in Addis Ababa City.

[36] Muli Emmanuel Kyalo. (2016). Factors Influencing Performance Of Women Entrepreneurs In Kenya: A Case Of Bungoma South. A Research Report Submitted In Partial Fulfillment Of The Requirement For The Award Of Master Of Arts Degree In Project Planning And Mana. Nirobi, Kenya

[37] Nasima Naznin Alam. (2014). Women Micro-Entrepreneurs in Bangladesh: Socio-Economic Aspects and Factors Affecting.

[38] Norma zatul Akma Saidia, Nursafeda Abd Rashida, Noraini Mohd Zinb, Hamidah Ramlanc, Norhanizah Joharid and Mohamad Ramzan Mohamade (2017). Determinants of Women Entrepreneurs' Performance in SMEs.
[39] Nxopo, Z. (2014). The Role of Government in Empowering Female Entrepreneurs in the Western Cape, South Africa. Master of Technology: Business Administration (Entrepreneurship). Cape Peninsula University of technology. Cape Town.

[40] Sarwoko E, \& Frisdiantara. C. (2015). Growth Determinants of Small Medium Enterprises (SMEs). Universal Journal of Management 4 (1): 36-41.

[41] Saunders M. Plewis P. Thorhill A. (2009). Research methods for Business Students (5th edition ed.). FT Prentice Hall: Mark Saunders, Philip Lewis and Adrian Thornhill 2009.

[42] Sharma, Y. (2013). Women entrepreneur in India. IOSR Journal of Business and Management, 15 (3): 9-14.

[43] Stefanovic, I., Prokic, S. and Rankovic, L. (2010). Motivational and success factors of entrepreneurs: the evidence from a developing country. Original Scientific Paper, 28 (2): 251-69.

[44] Sidek. S. \& Mohamad. M. R. (2014). Managerial Competencies and Small Business Growth: Empirical Evidence from Microfinance Participants. IJMS 21 (1), 3959 .

[45] Zulkiffli, S. \& Perera, N. (2011). A literature analysis on business performance for SMES - subjective or objective measures?. 2011 SIBR Conference on Interdisciplinary Business and Economics Research (pp. 1-9). Bangkok, Thailand: Society of Interdisciplinary.

[46] Tadesse Demeke (2016) Assessment of Challenges and Opportunities of Women Owned Micro and Small Enterprises: A Case of Asella Town, Research Journal of Finance and Accounting Vol. 7.

[47] Tsai, C. J., Edwards, P. \& Sengupta, S. (2010). The Association between Organizational Performance, Employee Attitudes and Human Resource Management Practices: An Empirical Study of Small Businesses, Journal of General Management, 36 (1), 1-20.

[48] UNECE (2004). Women's Self Employment and Entrepreneurship in the ECE region background. Paper prepared by the secretariat for the Regional Symposium on Mainstreaming Gender into Economic Policies. Geneva.

[49] Vinesh, L. (2014). Role of women entrepreneurs in India. Global Journal of Finance and Management. 6 (5) 473480.

[50] Vossenberg, S. (2013). Women entrepreneurship promotion in developing countries: what explains the gender gap in entrepreneurship and how to close it?: Available: http://www.msm.nl./resource/uploads

[51] Wasihun, R., \& Paul, I. (2010). Growth Determinants of Women-Operated Micro and Small Enterprises in Addis Ababa. Journal of Sustainable Development in Africa. Volume 12, No. 6, 233-246.

[52] Werotew Bezab. (2010): Entrepreneurship: An Engine for Sustainable Growth, Development, prosperity and Good Governance; Genius Training and Consultancy Service, Addis Ababa, Ethiopia.

[53] Wetherly, P., \& Otter, D. (2011). The Business Environment (2nd ed.). USA: Oxford University Press. 
[54] Wube, M. C. (2010), Factors Affecting the Performance of Women Entrepreneurs in Micro and Small Enterprises: A Case of Dessie Town. A Thesis Presented in Partial fulfillment of the Requirements for Degree of Master of Arts in Technical and Vocational Education Management, Bahir Dar University.

[55] World Bank (2014). Innovation, Technology \& Entrepreneurship Policy Note for Supporting Growth-Oriented Women Entrepreneurs: A Review of the Evidence and Key Challenges. Number 5 .

[56] Zaman, K., Javaid, N., Arshad, A. \& Bibi, S. (2012). Impact of Internal Marketing on Market Orientation and Business Performance, International Journal of Business and Social Science, 3 (12), 76-87.
[57] Zinash Abebe. (2014). Factors Affecting Women Entrepreneurs in Addis Ababa, unpublished masters theses available online.

[58] Zinashbizu Lemma Dagne. (2017). Challenges Facing Women Micro and Small scale Business Enterprise Owners in Jimma Town (Comparative study, Women enter in to the business by themselves and through Micro and small business enterprise office) International Journal of Scientific and Research Publications, Volume 7.

[59] Zororo, M. (2011). Characteristics and motivation in female entrepreneurship. Case of Botswana. University of Botswana Journal.

[60] Yamane, T. (1967). Statistics: An Introductory Analysis (2nd Ed ed.). 